\title{
A.B.C. LEADS IN ISCHÆMIC HEART DISEASE
}

\author{
BY \\ WILLIAM M. LANCASTER, THOMAS SEMPLE, AND JOHN C. C. KELLY \\ From the Department of Cardiology, The Victoria Infirmary, Glasgow \\ Received August 11, 1959
}

In 1953, Trethewie described a simplified method of electrocardiography that takes the form of a three-dimensional chest lead system. Further work (1958) led him to conclude that these new A.B.C. leads were superior to the conventional twelve-lead electrocardiogram in detecting and localizing myocardial infarction. The present paper gives the results of an investigation of the method designed to evaluate his conclusions. It does not confirm his claims entirely.

A.B.C. leads, in conjunction with standard twelve-lead cardiograms were performed in the wards and out-patient department of the Victoria Infirmary, Glasgow for three months in 1958-59 on the following groups of patients: (1) with clinical myocardial infarction, (2) presenting with angina pectoris, (3) complaining of chest pain not considered cardiac in origin, and (4) a miscellaneous group suffering from hypertension, paroxysmal tachycardia, valvular disease, and breathlessness.

Two other groups were studied separately: a group of normal young doctors and patients without constitutional disease, and a group found to have bundle-branch block in the standard leads.

All standard and A.B.C. leads were read separately and by more than one of the contributors. Unlike Trethewie, we have stipulated $Q$ wave changes for a diagnosis of infarction: $T$ wave changes we have labelled ischæmia. We have analysed our results, endeavouring to confirm or refute his claims, especially to answer the following questions. Do A.B.C. leads miss cardiac infarcts shown by the standard leads? Do A.B.C. leads reveal any cardiac infarcts missed by the standard leads? Do they aid interpretation, particularly regarding the presence of ischæmic heart disease, when the standard leads are equivocal, e.g. (a) when T is inverted in leads aVL or III, $(b)$ when there is bundle-branch block, and $(c)$ when there is left ventricular hypertrophy and strain. Can the A.B.C. leads replace the standard leads even as a screening test?

On the Technique of A.B.C. Electrocardiography. The use of the standard twelve-lead cardiogram in conventional electrocardiography is almost universally accepted. It is important to remember that basically these leads record only electrical activity of the heart in one plane, i.e. the frontal plane, and that electrical forces are produced in other planes. Considered in this fashion, the heart may be regarded as a three-dimensional source of energy situated in a volume conductor (the body). The resolving of the forces as spatial vectors in three planes at right angles to each other is the basis of vectorcardiography. The present paper evaluates a simple method of lead placement that likewise attempts to overcome the spatial limitations of the frontal plane leads, and gives a three-dimensional approach to electrocardiography.

The lead placements are shown in Fig. 1. Standard limb lead II electrodes are chosen, the left-leg lead being used as the fixed or xiphisternum lead and the right-arm lead as the exploring electrode in the following positions:

$$
\begin{aligned}
& \text { Frontal plane - (A) the posterior lead-manubrium sterni. } \\
& \text { Horizontal plane-(B) the anterior lead -position V6. } \\
& \text { Sagittal plane - (C) the septal lead -in line with angle of right } \\
& \text { scapula at same level as B. }
\end{aligned}
$$

Trethewie (1953 and 1958) has explained in great detail the theoretical considerations of the method and the interested reader is referred to these publications. 


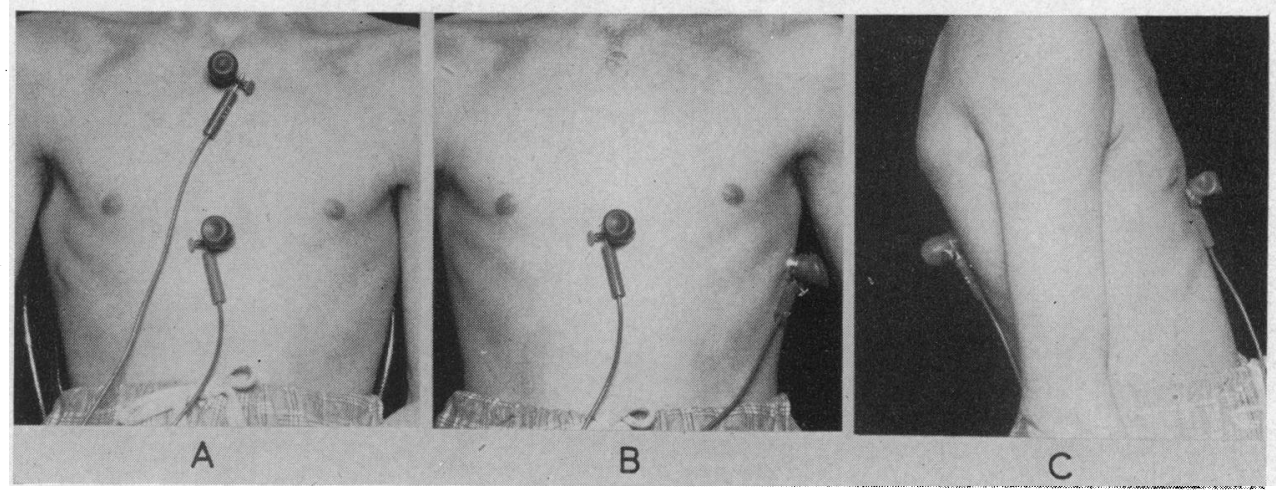

FIG. 1.-Photographs showing the lead positions.

\section{RESULTS}

Clinical Myocardial Infarct Series. During the three months of the study, there were 115 patients who presented with the clinical picture of myocardial infarction. Referring to Table I, it will be seen that the conventional twelve-lead cardiogram showed significant changes in 110 of these. Three patients had normal conventional leads and A.B.C. leads. Two patients had significant changes in A.B.C. leads only.

Column 1 shows a completely accurate correlation between the conventional and A.B.C. leads in 66 patients or 60 per cent. (This excludes the three who had normal tracings throughout.) Including Column 4, where A.B.C. leads confirm but show grosser changes (Fig. 2), correlation is increased to 82 or 75 per cent. Including Column 5 where A.B.C. leads show different or lesser changes or ischæmic disease, correlation is increased to 97 or 88 per cent. In the last column, agreement was rather tenuous, although both systems confirmed in each case the presence of ischæmic heart disease. In antero-septal infarction (6 cases) A.B.C. leads showed only ischæmic changes. With posterior infarction and ischæmia (6 cases) A.B.C. leads missed these but showed some other abnormality (Fig. 3); while in the combined infarctions (2 cases), posterior changes were again missed (Fig. 4).

Results in Non-Infarct Series. There were 183 patients in this group (Table II). In 94 of these, the conventional and A.B.C. tracings were normal. In 59, both methods showed abnormality with reasonable agreement. This total of 153 patients gives a correlation between the methods of 84 per cent. Of 13 patients $(7 \%$ ) whose A.B.C. leads showed no abnormality, 10 showed posterior changes in the standard tracings. Of 17 patients $(9 \%$ whose A.B.C. leads alone were abnormal, only two showed pure posterior changes, the remainder showing antero-septal changes, left ventricular strain, or combined infarct patterns.

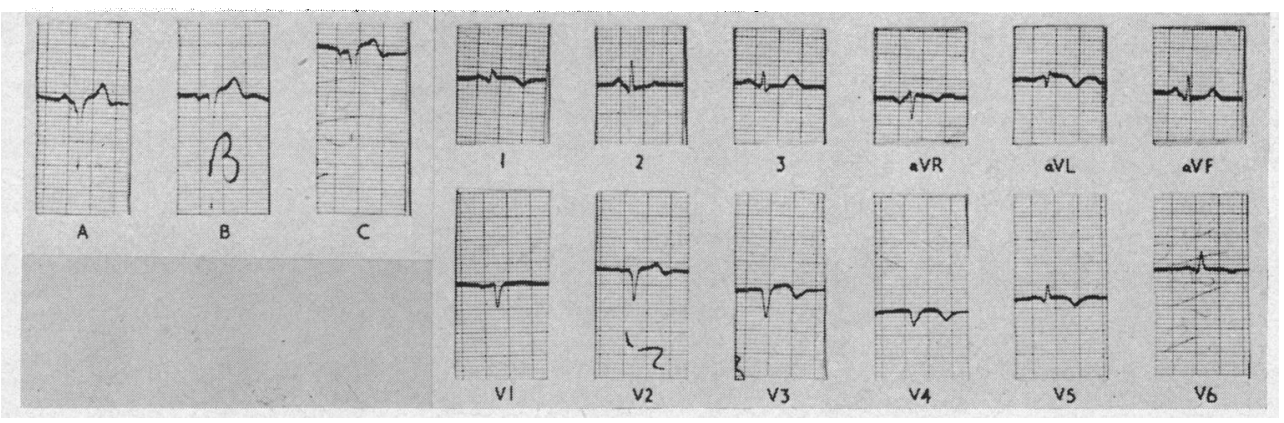

FIG. 2.-Acute antero-septal infarction in standard leads. A.B.C. leads show posterior infarction in addition. 
TABLE I

ANALYSIS OF "Clinical INFARCtion" Series

\begin{tabular}{|c|c|c|c|c|c|}
\hline Standard leads & $\begin{array}{l}\text { A.B.C. leads and } \\
\text { standard leads } \\
\text { in complete } \\
\text { agreement }\end{array}$ & $\begin{array}{l}\text { A.B.C. leads } \\
\text { normal }\end{array}$ & $\begin{array}{l}\text { Only A.B.C. } \\
\text { leads } \\
\text { abnormal }\end{array}$ & $\begin{array}{c}\text { A.B.C. changes } \\
\text { more extensive } \\
\text { than standard } \\
\text { leads }\end{array}$ & $\begin{array}{c}\text { A.B.C. changes less } \\
\text { extensive or suggest } \\
\text { different site of } \\
\text { lesion }\end{array}$ \\
\hline $\begin{array}{l}\text { Anterior Infarction } \\
\text { Antero-septal } \\
\text { Fresh }\end{array}$ & 17 & 1 & - & 6 & 4 \\
\hline Old or healing & 4 & - & - & 3 & 2 \\
\hline $\begin{array}{l}\text { Antero-lateral } \\
\text { Fresh }\end{array}$ & - & 1 & - & 1 & - \\
\hline Old or healing & - & 1 & - & 1 & - \\
\hline $\begin{array}{l}\text { Anterior Ischamia } \\
\text { Antero-septal }\end{array}$ & 6 & - & 2 & - & - \\
\hline $\begin{array}{l}\text { Antero-lateral or } \\
\text { L.V. strain }\end{array}$ & 3 & 1 & 一 & - & 1 \\
\hline $\begin{array}{l}\text { Posterior Infarction } \\
\text { Fresh }\end{array}$ & 11 & 1 & - & 4 & 3 \\
\hline Old or healing & 6 & 4 & 一 & 1 & - \\
\hline Posterior Ischamia & 5 & 3 & - & - & 3 \\
\hline $\begin{array}{l}\text { "Combined" Infarcts } \\
\text { Fresh }\end{array}$ & 7 & - & - & - & 1 \\
\hline Old or healing & 5 & 1 & - & - & 1 \\
\hline Widespread Ischamia & 2 & - & - & - & - \\
\hline Normal & 3 & - & 一 & - & - \\
\hline TOtaL .. & 69 & 13 & 2 & 16 & 15 \\
\hline
\end{tabular}

Normal Findings. Our healthy volunteers all produced A.B.C. tracings that we have learned to expect to be associated with physiological twelve-lead cardiograms. One disappointing feature of the A.B.C. method is that inverted T waves are common in lead B in such healthy people; they seem to have no more significance than the commonly inverted $T$ in lead VI (Fig. 5).

Bundle-Branch Block. During the three months of the investigation, we encountered 12 examples of bundle-branch block. All had clinical evidence of ischæmic heart disease but were excluded from the infarct and the angina series. They included seven examples of left bundle-branch block, two of complete right bundle-branch block and two of partial right bundle-branch block. In addition, one patient, whose tracings are shown in Fig. 6 had left bundle-branch block related to a minute septal infarct (confirmed at autopsy) which later changed to right bundle-branch block before death.

We found that A.B.C. leads are as helpful as conventional leads for showing bundle-branch block but no more helpful in clarifying the presence or absence of accompanying myocardial infarction.

\section{Discussion}

Were the A.B.C. method shown to be as accurate as Trethewie claims in the diagnosis of myocardial infarction, it could be acclaimed a major advance in electrocardiography and one might even consider it replacing entirely the conventional twelve-lead method. The three leads are quickly 
TABLE II

Result In Non-INFARCt Series

\begin{tabular}{|c|c|c|c|c|c|c|}
\hline \multirow{2}{*}{$\begin{array}{l}\text { A.B.C. and conventional leads, both } \\
\text { normal }\end{array}$} & \multicolumn{2}{|l|}{ Angina group } & \multicolumn{2}{|c|}{ Chest pain group } & \multicolumn{2}{|l|}{ Miscellaneous group } \\
\hline & - & 40 & - & 29 & 一 & 25 \\
\hline $\begin{array}{l}\text { A.B.C. and conventional leads, both } \\
\text { diagnostic } \\
\text { (1) Ischæmia or L.V. hypertrophy } \\
\text { and strain }\end{array}$ & - & 23 & - & 1 & - & 24 \\
\hline (2) Myocardial infarct & $\begin{array}{l}\begin{array}{l}\text { Former antero- } \\
\text { septal infarcts }\end{array} \\
\begin{array}{l}\text { Former posterior } \\
\text { infarcts }\end{array} \\
\begin{array}{ll}\text { inf } & 2\end{array}\end{array}$ & 4 & 一 & 1 & $\begin{array}{lll}\text { Old posterior } & \ldots 2 \\
\text { Antero-septal } & \ldots 4\end{array}$ & \\
\hline $\begin{array}{l}\text { Conventional leads alone diagnostic } \\
\text { (1) Ischæmia }\end{array}$ & $\begin{array}{l}\text { Posterior ischæmia } 4 \\
\text { Ant. ischæmia (or } \\
\text { L.V. strain) } \quad \text {. } 1\end{array}$ & 5 & $\begin{array}{l}\text { Both showing } \\
\text { posterior } \\
\text { ischæmia. }\end{array}$ & 2 & $\begin{array}{l}\text { Posterior ischæmia } 1 \\
\text { L.V. strain } \quad \ldots 1\end{array}$ & \\
\hline (2) Myocardial infarction & $\begin{array}{l}\text { Former posterior } \\
\text { infarcts }\end{array}$ & 2 & - & Nil & $\begin{array}{lll}\text { Posterior infarct } & 1 \\
\text { Antero-septal } & \ldots & 1\end{array}$ & \\
\hline $\begin{array}{l}\text { A.B.C. leads alone diagnostic } \\
\text { (1) Ischæmia }\end{array}$ & 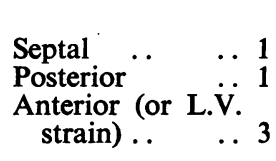 & 5 & $\begin{array}{l}\text { Antero-septal } \\
\text { ischæmia in } \\
\text { each case. }\end{array}$ & 3 & 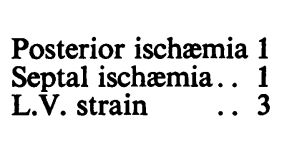 & 5 \\
\hline (2) Myocardial infarction & Antero-posterior* 2 & 2 & - & Nil & $\begin{array}{l}\text { Old antero-posterior } \\
\text { infarcts in both } \\
\text { cases. }\end{array}$ & 2 \\
\hline .. $\quad \ldots 183$ patients & 一 & 81 & - & 36 & 一 & 66 \\
\hline
\end{tabular}

* In one of these, standard cardiograms showed an extensive ischæmic picture.

recorded and read; there is no doubt in our minds that they show a high degree of accuracy in portraying antero-septal infarctions. Left ventricular hypertrophy and strain are well demonstrated in lead B which shows in such cases a deep S wave and elevated S-T segment. Arrhythmias and bundle-branch block are satisfactorily represented. Abnormal $P$ waves are well shown in lead A (inverted and biphasic $\mathbf{P}$ waves are common in leads $\mathrm{B}$ and $\mathrm{C}$ of normal subjects, rather like lead V1).

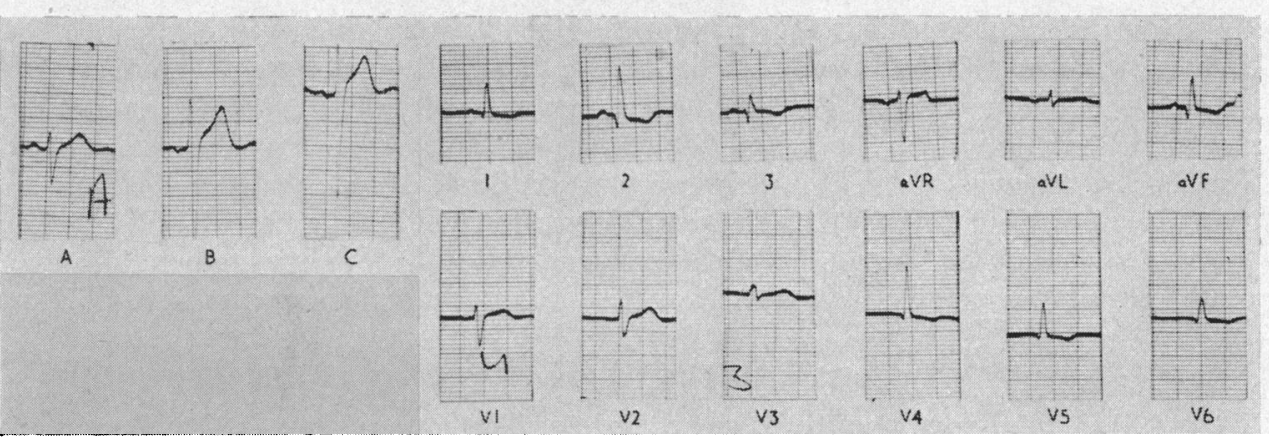

FIG. 3.-Old subendocardial posterior infarct with evidence of left ventricular stress. Only the latter is confirmed in A.B.C. tracings. 


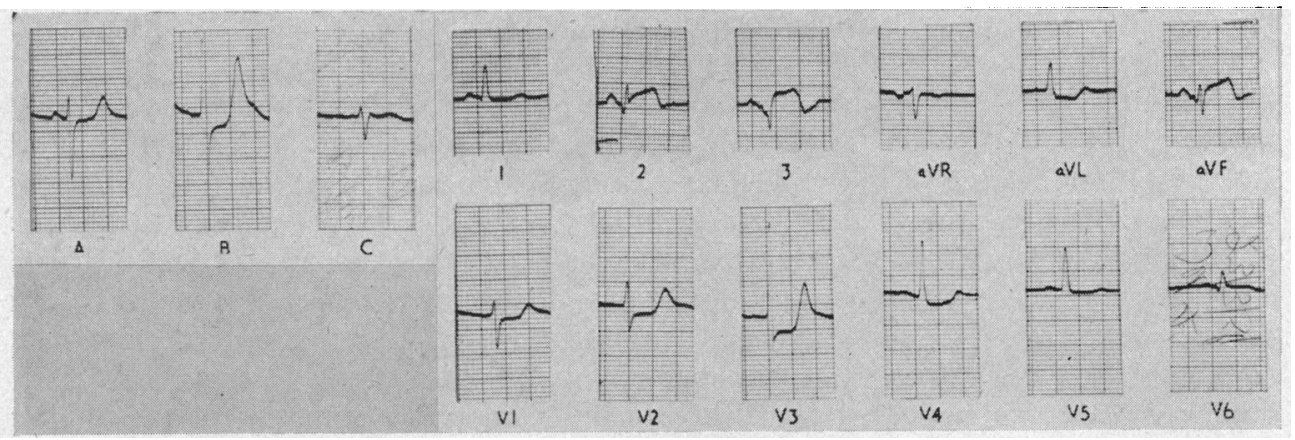
FIG. 4.-Acute posterior infarction with septal ischæmia. A.B.C. leads show antero-septal

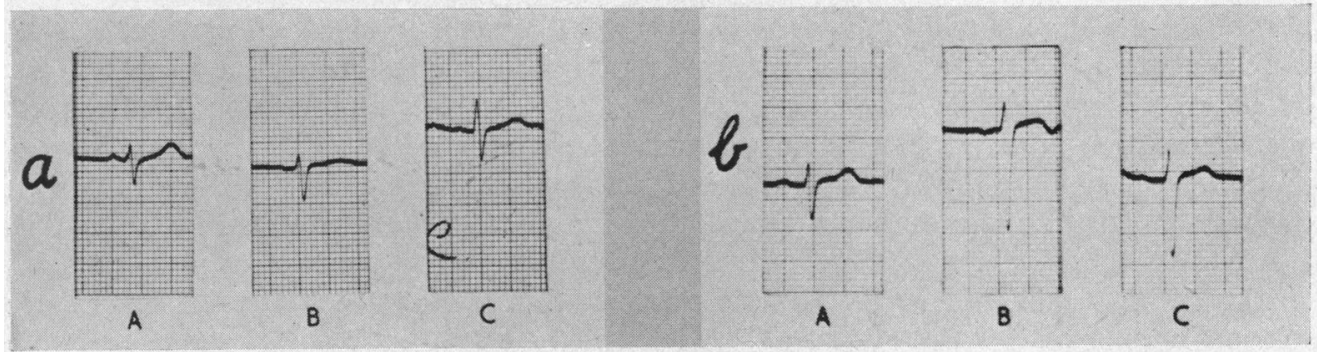

FIG. 5.-Normal A.B.C. tracings. Note biphasic $T$ wave in lead $B$ in (b).

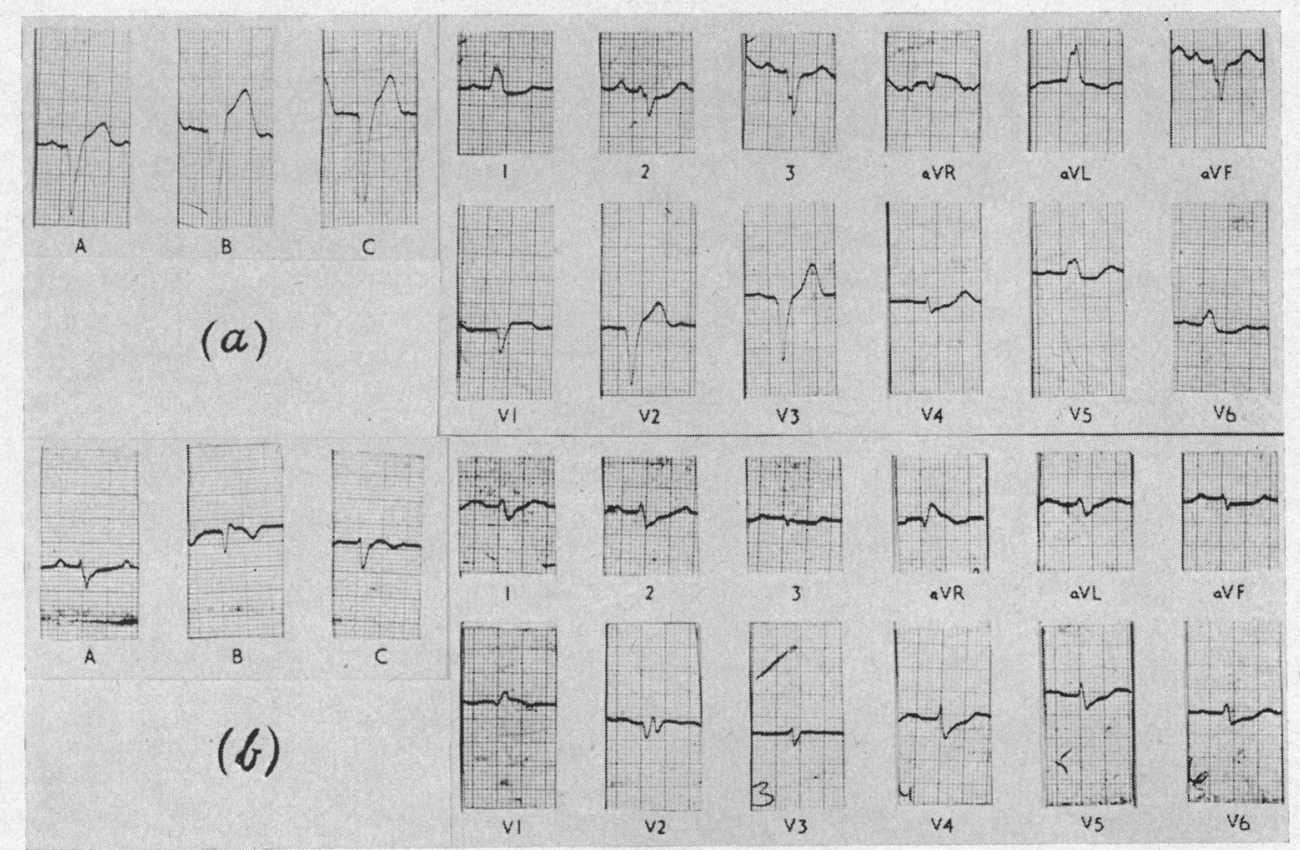

FIG. 6.-(a) Left bundle-branch block. (b) Tracings of same patient four days after (a) with change to right bundle-branch block. 
Certain critìcisms, however, became apparent during our investigations, some minor but others more vital. Thus we found respiratory variations and somatic tremor common, especially in lead C. R waves in all three leads tend to be small and it is difficult to be certain about the significance of an apparently absent $R$ wave. Especially is this the case in lead $B$ which tends to mimic leads $\mathrm{V} 1$ and $\mathrm{V} 2$, in that inverted $\mathrm{T}$ is frequent and normal and some elevation of the $\mathrm{S}-\mathrm{T}$ segment common. Owing to predominance of $S$ waves in all three leads, $q R$ patterns, as distinct from QS patterns, are rarely seen in myocardial infarction. Lastly, and most important, lead A has failed to confirm about one-third of the posterior infarctions and ischæmic cases shown by the conventional twelve-lead cardiograms. Trethewie did not demonstrate in his series this "posterior blind spot," and he did claim that the new method was superior, mainly in showing up septal infarcts.

It is interesting to find that the overall agreement is about the same in the two infarct series under consideration. Trethewie's series of 168 (collected over 6 years) showed complete agreement in $127(79 \%$ ). Our complete agreement rate was 75 per cent when we included these patients whose A.B.C. leads were confirmatory but were even more pathological. Here the similarity of our findings ceases, for Trethewie found that in $24(15 \%)$ the A.B.C. leads showed the presence of myocardial infarction when the conventional leads were not diagnostic, while we found this only applied in two patients, each of whom showed minimal septal ischæmic lesions (Table I, column 3). We found that A.B.C. leads failed to detect changes in $13(12 \%)$ patients who had abnormal conventional tracings, while the original series contains no such examples.

It is difficult to analyse further this rather disturbing anomaly, because Trethewie (1958) includes only one example that illustrates the simultaneous comparison of a conventional twelve-lead electrocardiogram and A.B.C. tracings. This example claims to show the presence of myo-cardial infarct only in the A.B.C. leads, but we would have no hesitation in diagnosing a septal infarct from the conventional chest leads shown.

Electrocardiograms are open to biased interpretation by a single protagonist of a new method and so one might expect our conclusions to be more reliable in view of our careful attention to the method of duplicate and separate interpretation of all tracings.

\section{SUMMARY}

A.B.C. leads have confirmed the presence of ischæmic heart disease in a high proportion of patients $(88 \%)$ with a diagnostic history and conventional twelve-lead electrocardiogram. The identical interpretation correlation was 60 per cent.

From this preliminary investigation one cannot confirm Trethewie's claim that "the A.B.C. display detects all cases of infarction shown by the present standard leads." In our series with clinical infarction, the standard leads showed changes in 13 patients who had normal A.B.C. tracings. In fact, the-A.B.C. leads demonstrated minor changes in only two patients in the infarct series who had not significant standard lead changes.

A.B.C. leads portray well the change of left ventricular hypertrophy and bundle-branch block, but do not help any more than do standard tracings to decide whether myocardial infarction is present in such patients. They do not appear to further the accuracy of diagnosis in patients having uncertain standard lead changes such as $\mathrm{T}$ inversion in aVL or lead III.

We doubt whether the method furthers accuracy in diagnosis, or even its value as a screening test. Our main criticism is the apparent relative inaccuracy of the posterior lead A.

Our thanks are due to Dr. A. A. F. Peel for his help and advice in the preparation of this paper, to Miss M. Moore and Staff of the Cardiographic Department, and to Mr. H. C. Gray, for photographic reproductions.

\section{REFERENCES}

Trethewie, E. R. (1953). Simplified Electrocardiography. Melbourne University Press. (1958). Brit. med. J., 1, 1428. 